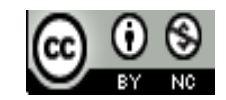

Jurnal Pendidikan Matematika Indonesia is licensed under

A Creative Commons Attribution-Non Commercial 4.0 International License.

\title{
ANALISIS KESULITAN MAHASISWA DALAM PENYUSUNAN PROPOSAL PENELITIAN PENDIDIKAN MATEMATIKA
}

\author{
Farida Daniel ${ }^{1)}$, Prida N. L. Taneo ${ }^{2)}$ \\ 1) STKIP Soe, Soe, Indonesia \\ E-mail: staffaridaniel@stkipsoe.ac.id \\ 2) STKIP Soe, Soe, Indonesia \\ E-mail: stafpridataneo@stkipsoe.ac.id
}

\begin{abstract}
Abstrak. Penelitian ini bertujuan untuk mengetahui jenis kesulitan dan faktor-faktor penyebab kesulitan mahasiswa dalam menyusun proposal penelitian pendidikan matematika. Jenis penelitian ini adalah deskriptif kualitatif dengan subjek penelitian adalah mahasiswa program studi pendidikan matematika STKIP Soe yang mengambil matakuliah seminar proposal sejumlah 21 orang. Metode pengumpulan data dalam penelitian ini adalah observasi, wawancara dan dokumentasi. Teknik analisis data mengikuti model Miles dan Huberman yang meliputi reduksi data, penyajian data dan penarikan kesimpulan. Hasil penelitian menunjukkan bahwa jenis-jenis kesulitan mahasiswa dalam menyusun proposal penelitian pendidikan matematika adalah kesulitan dalam menuangkan ide ke dalam bentuk tulisan ilmiah, membuat latar belakang masalah, mencari literatur/bahan pustaka, mengkaji keterkaitan teori yang digunakan menentukan metodologi penelitian serta membagi waktu kuliah dengan penyusunan proposal penelitian. Faktor-faktor penyebab kesulitan tersebut berupa faktor internal dan eksternal. Faktor internal meliputi masih rendahnya kemampuan mahasiswa dalam memahami setiap konten dalam proposal penelitian, masih terdapat mahasiswa yang belum memiliki komputer atau laptop sendiri serta beberapa mahasiswa kurang termotivasi dalam menyelesaikan proposal penelitiannya. Faktor eksternal meliputi terdapat mahasiswa yang terlibat dalam kegiatan sosial maupun kerohanian di lingkungan rumahnya, mahasiswa yang sudah berkeluarga sulit berkonsentrasi karena gangguan dari keluarganya serta kesibukan mahasiswa dalam menyelesaikan berbagai tugas di rumah karena tinggal bersama pengampuh/orang tua wali.
\end{abstract}

Kata kunci: kesulitan mahasiswa, pendidikan matematika, proposal penelitian.

\section{PENDAHULUAN}

Salah satu profil lulusan dari program studi S1 pendidikan pendidikan matematika STKIP Soe adalah menjadi peneliti pendidikan matematika yaitu orang yang melakukan pengumpulan, pengolahan, analisis dan penyajian data yang dilakukan secara sistematis dan objektif untuk memecahkan suatu persoalan atau menguji suatu hipotesis untuk mengembangkan prinsip-prinsip umum dibidang pendidikan matematika. Pencapaian profil lulusan ini didukung oleh pemberian mata kuliah bidang kajian penelitian sehingga mahasiswa memiliki penguasaan pengetahuan dan kemampuan kerja dalam pelaksanaan penelitian.

Penelitian adalah penyaluran rasa ingin tahu manusia terhadap suatu masalah dengan menggunakan perlakuan tertentu seperti memeriksa, mengusut, menelaah dan mempelejari secara cermat serta memformulasikan hipotesis terhadap suatu masalah sehingga diperoleh suatu pencapaian kebenaran jawaban atas masalah, pengembangan ilmu pengetahuan dan sebagainya (Siregar, 2014:8). Suatu penelitian termasuk penelitian pendidikan matematika dapat terlaksana dengan baik jika metode yang digunakan sesuai dengan permasalahan yang ada. Metode penelitian pendidikan adalah cara ilmiah untuk mendapatkan data yang valid dengan tujuan dapat ditemukan, dikembangkan dan dibuktikan, suatu pengetahuan tertentu sehingga pada gilirannya dapat digunkan untuk memahami, memecahkan dan mengantisipasi masalah dalam bidang pendidikan (Sugiyono, 2013:6)

Beberapa persyaratan yang harus terpenuhi dalam melakukan penelitian antara lain sistematis, ilmiah dan terencana. Sistematis dan ilmiah berarti penelitian harus dilaksanakan menurut pola tertentu dan mengikuti konsep ilmiah sedangkan terencana berarti penelitian dilaksanakan dengan unsur kesengajaan dan telah dipikirkan langkahlangkah pelaksanaannya (Siregar, 2014:8). Kriteria penelitian yang baik adalah pelaksanaan penelitian harus dirancang secermat mungkin. (Siregar, 2014: 9). 
Rancangan atau proposal penelitian merupakan pedoman yang berisi langkah-langkah yang akan diikuiti oleh peneliti untuk melakukan penelitiannya. Dalam menyusun rancangan penelitian perlu diantisipasi tentang berbagai sumber yang dapat digunakan untuk mendukung dan yang menghambat terlaksananya penelitian. Rancangan penelitian atau proposal penelitian harus dibuat secara sistematis dan logis sehingga dapat dijadikan pedoman yang betul-betul mudah diikuti (Sugiyono, 2013:383).

Seminar proposal merupakan mata kuliah wajib semester VI yang memberikan pengertian dan penguasaan kepada mahasiswa tentang prosedur pembuatan proposal penelitian sesuai dengan peraturan akademik yang berlaku, cara memaparkan isi proposal dan argumentasi terhadap isi proposal dalam seminar. Mata kuliah ini memiliki peranan penting dalam mendukung mahasiswa dalam mengerjakan tugas akhir sebagai syarat penyelesaian studi nantinya.

Sebagai suatu tuntutan akademik, mahasiswa program Sarjana (S1) harus mampu mengembangkan suatu penelitian ilmiah di bidang ilmunya. Mengawali proses penulisan tugas akhir, mahasiswa menjalani rancangan penelitian dengan menuliskan proposal sebagai salah satu rangkaian mata kuliah penelitian yang harus diselesaikan. Format penulisan tentang penggunaan font, layout dan cara pengutipan mengikuti tata tulis yang sama dengan tugas akhir.

Proses perkuliahan seminar proposal terdiri dari pendampingan dosen pengampu mata kuliah dalam tahapan penyusunan setiap bagian proposal kemudian mahasiswa akan mempresentasikan dan mempertanggung jawabkan proposalnya. Hasil observasi selama proses perkuliahan seminar proposal menunjukkan sebagian besar mahasiswa masih mengalami kesulitan dalam menyusun proposal penelitian yang merupakan luaran dari mata kuliah ini. Hal ini ditandai oleh sebagian besar mahasiswa masih kesulitan menuliskan idenya sendiri, kesulitan membuat latar belakang masalah, kesulitan memilih metode penelitian yang tepat dan cenderung mengutip proposal yang sudah ada atau yang mereka peroleh dari internet sehingga berdampak pada kurangnya kemampuan mahasiswa dalam mempertahankan ide dalam proposal yang dibuatnya. Hal ini serupa dengan penelitian yang dilakukan oleh Xia dan Luxin (2012:330) menyatakan bahwa dalam menulis proposal tesis siswa kesulitan dalam menentukan topik penelitian, kesulitan, merancang desain penelitian, mengelompokkan genre atau jenis proposal tesis dan kecukupan literatur.

Menurut Syah (2011:132) kesulitan mahasiswa dipengaruhi oleh beberapa faktor yaitu faktor internal (faktor yang berasal dari dalam diri) dan faktor eksternal (faktor yang berasal dari luar). Suryabrata (2014:233) mengungkapkan yang termasuk faktor internal adalah fisiologis dan psikologis (misalnya: kecerdasan, motivasi, prestasi, dan kemampuan kognitif). Faktor eksternal adalah faktor lingkungan dan instrumental (misal: sekolah, guru, kurikulum dan model pembelajaran). Hasil penelitian Asmawan (2016:52) menyatakan faktor yang menghambat mahasiswa dalam menyelesaikan skripsi adalah faktor internal yang meliputi motivasi dan kemampuan mahasiswa dalam menulis skripsi sedangkan faktor eksternal meliputi lingkungan, sistem pengelolaan skripsi oleh fakultas, dosen pembimbing

Kesulitan mahasiswa perlu di analisis untuk mencari jenis kesulitan dan faktor penyebab kesulitan itu terjadi. Informasi tentang kesulitan dalam menyusun proposal penelitian yang digunakan untuk meningkatkan kemampuan mahasiswa dan dapat membantu dalam mengatasi masalah yang menyebabkan mahasiswa mengalami kesulitan. Dengan mengetahui kesulitan dalam pembelajaran yang sesuai dengan kebutuhan anak maka pendidik dapat lebih mudah mengatur kondisi anak yang mengalami kesulitan belajar. Tujuan dari penelitian ini adalah untuk mengetahui jenis-jenis kesulitan serta faktor penyebab kesulitan mahasiswa dalam menyusun proposal penelitian pendidikan matematika.

\section{METODE PENELITIAN}

Penelitian ini menggunakan metode deskriptif kualitatif dan dilaksanakan pada mahasiswa program studi pendidikan matematika STKIP Soe yang mengambil mata kuliah seminar proposal pada semester genap, tahun akademik 2016/2017. Teknik pengumpulan data yang digunakan dalam penelitian ini berupa (1) observasi, digunakan untuk memperoleh informasi mengenai cara mahasiswa dalam menyusun proposal; (2) wawancara, digunakan untuk memperoleh informasi mengenai faktor-faktor penyebab kesulitan mahasiswa dalam menyusun proposal. Wawancara yang dilakukan adalah wawancara semi terstruktur. Subjek yang diwawancarai adalah seluruh mahasiswa yang mengambil mata kuliah seminar proposal yaitu 21 orang; (3) dokumentasi, data yang diperoleh dari studi dokumentasi berupa proses pembelajaran pada mata kuliah seminar proposal, proposal mahasiswa dan hasil wawancara.

Teknik analisis data dalam penelitian ini mengikuti model Miles dan Huberman yang mencakup pengumpulan data, reduksi data dan penarikan kesimpulan. Pengumpulan data kesulitan mahasiswa dilakukan melalui observasi dan wawancara. Reduksi data meliputi kegiatan merangkum dan memilih hal-hal pokok yang difokuskan untuk mendapatkan pola penelitian yaitu kesimpulan tentang kesulitan yang dihadapi mahasiswa dalam penyusunan proposal tugas akhir. Pengujian keabsahan data dalam penelitian ini menggunakan triangulasi teknik.

\section{HASIL DAN PEMBAHASAN}

Observasi dan wawancara menunjukkan bahwa kesulitan mahasiswa dalam penyusunan proposal penelitian pendidikan matematika adalah sebagai berikut:

\section{Kesulitan menuangkan ide ke dalam bentuk tulisan ilmiah}

Jenis kesulitan ini adalah mahasiswa sulit memahami bagaimana cara menulis ide atau menuangkan data dalam bentuk tulisan. Letak kesulitan ini ditandai dengan ditemukannya beberapa bentuk kesalahan berbahasa seperti kesalahan ejaan, kesalahan diksi, kesalahan penyusunan kalimat dan kesalahan paragraf pada proposal yang disusun. Kesalahan ejaan meliputi kesalahan penggunaan huruf kapital, penggunaan huruf miring, penulisan kata turunan, penulisan singtkatan dan akronim, penggunaan tanda titik, penggunaan 
tanda koma, penggunaan tanda hubung dan penulisan kata depan. Kesalahan diksi meliputi ketepatan kata dan kelaziman kata. Kesalahan penyusunan kalimat mencakup kalimat yang tidak hemat atau tidak ekonomis, pengulangan makna, kalimat yang tidak lengkap karena subjek tidak jelas. Kesalahan paragraf meliputi masalah kohesi, koherensi, dan kelengkapan dalam paragraf.

Kesulitan ini terjadi karena kurangnya penguasaan kaidah kebahasaan mahasiswa, ketidaktelitian dalam menulis dan kurangnya kosakata mahasiswa. Hasil ini sejalan dengan penelitian Ayudia, dkk (2017:10) yang menyatakan kesalahan berbahasa terjadi karena siswa belum memahami dan menguasai tata cara penulisan ejaan ragam baku, kosakata yang dimiliki terbatas, dan kurang menguasai penyusunan kalimat efektif. Seseorang yang minim kosakatanya akan mengalami kesulitan dalam menentukan kata yang tepat untuk menyampaikan gagasannya. Hal ini didukung oleh hasil wawancara dengan mahasiswa dengan transkrip sebagai berikut:

P : Mengapa dalam proposal anda khususnya pada bagian latar belakang, anda sering mengulang-ulang kalimat yang maknanya sama pada beberapa paragraf?

M-02 : Saya masih bingung menuliskan kalimat lanjutan yang tetap punya kaitan dengan kalimat sebelumnya makanya jadinya mengulang-ulang

$P \quad$ : Coba dijelaskan bingungnya karena apa?

MO2 : Saya masih ragu memilih kata-kata yang cocok sesuai dengan yang ada di pikiran saya.

$P \quad$ : Jadi maksud anda, anda sulit membahasakan apa yang anda pikirkan?

M02 : Iya. Saya coba merangkainya dalam pikiran saya kemudian menuliskannya hanya saja kalimat yang saya tuliskan belum mewakili sepenuhnya maksud saya.

$P \quad$ : Lalu apa yang anda lakukan untuk memperbaiki kalimat tersebut?

M02 : Saya coba membaca kembali supaya bisa memperbaikinya tetapi karena bingung membuat kalimat baru saya tinggalkan saja seperti itu.

$P \quad$ : Iya. Beberapa kalimat yang anda tuliskan juga maknanya kurang jelas karena kata hubung yang anda gunakan kurang tepat seperti harusnya kata "kepada" anda gunakan "bagi". Mengapa seperti itu?

M-02 : Menurut saya kata itu sudah tepat makanya saya tuliskan seperti itu.

P : Lalu bagaimana dengan beberapa kesalahan penulisan kata depan dan juga penggunaan huruf kapital?

M-02 : Saya kurang teliti untuk penulisan huruf kapital sedangkan penulisan kata depan saya lupa aturannya.

\section{Kesulitan dalam membuat latar belakang masalah}

Kesulitan ini mencakup penentuan lokasi penelitian, penentuan variabel penelitian, gambaran permasalahan khusus dilokasi penelitian dan solusi terhadap permasalahan tersebut. Sebagian mahasiswa masih bingung menetapkan lokasi penelitian karena kurangnya akses secara individu ke lokasi yang mempermudah observasi terkait permasalahan yang terjadi. Mahasiswa juga kesulitan menentukan batasan untuk variabel mana yang akan diteliti dan gambaran permasalahan terkait variabel tersebut masih kurang.

Studi pendahuluan dalam suatu penelitian perlu dilakukan agar peneliti dapat memahami topik atau permasalahan yang akan diteliti. Hal ini dapat dilakukan dengan melakukan studi pustaka, wawancara dan kunjungan ke lokasi penelitian (Siregar, 2014:25). Studi pendahuluan yang dilakukan sebagian besar mahasiswa masih kurang mendalam. Gambaran latar belakang masalah beberapa mahasiswa hanya berdasarkan hasil wawancara atau observasi saja serta tidak terprogram dengan rinci sehingga kurang bisa menemukan titik-titik permasalahan di lokasi. Mahasiswa juga kurang memahami gejala-gejala yang terjadi saat observasi awal dilokasi maupun kurang membaca penelitian-penelitian yang relevan. Secara umum mahasiswa cenderung suka menyalin tulisan yang sudah ada sehingga kesulitan mempertanggungjawabkan solusi yang diambil untuk permasalahan yang ada. Hal ini didukung oleh hasil wawancara dengan mahasiswa seperti pada transkrip berikut:

$P \quad$ : Mengapa permasalahan yang anda sajikan pada bagian latar belakang masih sangat umum?

M-10 : Saya bingung membuat penjelasan yang lebih khusus.

$P \quad: \quad$ Iya bingungnya seperti apa?

M-10 : Saat saya observasi proses pembelajaran di kelas, permasalahan yang saya temukan bervariasi. Saya masih bingung menentukan fokus masalah penelitian sehingga saya menuliskannya seperti itu.

$P \quad: \quad$ Selain observasi apakah anda melakukan hal lain untuk bisa menemukan fokus masalah penelitian?

M-10 : Ada, saya mewancarai guru mata pelajaran matematika.

$P \quad$ : Lalu hasilnya bagaimana?mengapa tidak dituliskan semua di proposalmu?

M-10 : Saya bingung menyimpulkan hasil wawancara dan observasi.

$P \quad$ : Iya, lalu bagaimana anda kemudian memberikan solusi untuk permasalahan yang masih umum yang sudah anda tuliskan sebelumnya?

M-10 : Saya baca proposal kakak semester seperti itu ibu makanya saya ikut saja

$P \quad: \quad$ Sudah baca artikel lain tentang penelitian yang relevan dengan masalah penelitianmu atau hanya mengutip dari senior?

M-10 : Sudah ibu tapi hanya 3 artikel yang saya dapatkan. 


\section{- - - Jurnal Pendidikan Matematika Indonesia \\ Volum 4 Nomor 2 bulan September 2019 Page 79 - 83 \\ p-ISSN: 2477-5967 e-ISSN: 2477-8443}

\section{Kesulitan mencari literatur/bahan pustaka}

Kesulitan ini mencakup ketersediaan, kejelasan dan ketepatan referensi yang digunakan dalam penyusunan proposal penelitian. Kesulitan dalam ketersediaan referensi ditandai oleh kebanyakan mahasiswa menggunakan referensi sekunder untuk buku maupun jurnal yaitu mengutipnya dari proposal yang sudah ada tanpa ada usaha untuk memiliki dan membaca sendiri dari referensi tersebut. Beberapa referensi yang digunakan mahasiswa juga berasal dari jurnal yang identitasnya kurang lengkap sedangkan beberapa referensi kurang relevan dengan permasalahan yang dibahas. Dalam suatu penelitian jika teori yang digunakan tidak relevan dengan penelitian yang dilakukan dapat mengakibatkan hasil penelitian tidak optimal (Siregar, 2014:27). Literatur sebagai bahan kajian berguna sebagai pembahasan variabel penelitian dan sebagai landasan untuk merumuskan hipotesis penelitian. Literatur dapat ditemukan dibanyak sumber seperti perpustakaan, internet, jurnal dan lain sebagainya.

Kesulitan ini terjadi disebabkan karena kurangnya usaha mahasiswa mencari referensi jurnal maupun buku yang tepat. Selain itu jumlah literatur yang tersedia diperpustakaan STKIP Soe juga belum memadai sehingga mahasiswa kemudian mencari referensi lain ke perpustakaan Daerah Kota Soe atau meminjamnya pada dosen. Hal ini didukung oleh hasil wawancara dengan mahasiswa seperti pada transkrip berikut:

$P \quad$ : Saya membaca tulisan anda di bab 2 dan masih sangat kurang khususnya pada kajian penelitian yang relevan dan juga teori yang mendukung. Mengapa demikian?

M-5 : Saya kekurangan referensi.

$P \quad$ : Memangnya yang sudah dituliskan disini referensinya dari mana?

M-5 : Saya kebanyakan mengutipnya dari proposal kakak semester.

$P \quad$ : Selain proposal kakak semester memangnya sudah mencari referensi dimana saja?

M-5 : Saya coba cari buku di perpustakaan dan juga unduh beberapa jurnal hanya tidak semua relevan dengan penelitian saya.

$P \quad: \quad B e r a p a$ lama mencarinya?

M-5 : Saya beberapa kali ke perpustakaan dan mencoba mengunduh jurnal hanya yang saya peroleh kurang relevan dengan penelitian saya. Jadi saya tidak cari lagi dan biarkan seperti itu bab 2 dan 3 saya.

$P \quad$ : Harus tekun mencari referensi jangan cepat putus asa, sudah coba cari lagi referensinya?

M-5 : Belum lagi.

\section{Kesulitan mengkaji keterkaitan teori yang digunakan}

Kesulitan ini ditandai dengan sebagian mahasiswa pada umumnya menulis deskripsi teori yang didapat dari berbagai sumber, tetapi tidak mengkaji/menjelaskan teori tersebut lebih jelas sesuai dengan kebutuhan penelitian yang dilakukan. Kesulitan ini terjadi disebabkan karena mahasiswa sulit menemukan keterkaitan antar teori yang digunakan dan relevansinya dengan penelitian. Hal ini sejalan dengan penelitian Xia dan Luxin (2012:332) yang menyatakan dalam kajian pustaka siswa kesulitan menemukan hubungan banyak penelitian sebelumnya agar secara logika sesuai dan mendukung penelitiannya sendiri. Hasil wawancara dengan mahasiswa terkait kesulitan ini disajikan pada kutipan berikut:

$P \quad$ : Bagaimana cara anda memilih dan menuliskan teori-teori dan penelitian terdahulu di bab 2?

M-17 : Saya melihat judul penelitian dan juga isi teori yang sesuai dengan penelitian saya.

$P \quad$ : Maksud anda sesuai itu yang seperti apa?

M-17 : Yang mendukung atau sejalan dengan penelitiaan saya.

$P \quad$ : Iya, mengapa tidak dijelaskan sekalian bentuk dukungan dalam tulisan anda?

M-17 : Saya masih sulit membahasakan dalam kalimat makanya dibiarkan begitu saja.

\section{Kesulitan menentukan metodologi penelitian}

Kesulitan ini ditandai dengan kebanyakan mahasiswa masih cenderung mengutip metode penelitian yang sudah pernah ditulis dalam berbagai penelitian yang sudah ada khususnya dari referensi jurnal yang mereka unduh atau proposal milik senior mereka. Mahasiswa belum mamahami dan menguasai serta sulit menentukan metode penelitian yang sesuai dengan masalah dan tujuan penelitian. Mahasiswa juga masih bingung menentukan teknik pengumpulan data, instrumen dan teknik analisis yang sesuai dengan permasalahan penelitiannya

Kesulitan ini terjadi karena mahasiswa belum menguasai dengan baik tentang metodologi penelitian yang mereka peroleh pada mata kuliah penelitian pendidikan matematika yang mereka peroleh pada semester yang sama. Selain itu pemahaman mahasiswa terkait statistika penelitian juga masih rendah sehingga kesulitan menyusun hipotesis dan rumusan statistik pengujian yang digunakan dalam penelitian kuantitatif. Hal ini sejalan dengan penelitian Rismen (2015:57) yang menyatakan bahwa kesulitan mahasiswa dalam penyelesaian skripsi adalah kesulitan dalam penuangan ide ke dalam tulisan ilmiah, penggunaan ilmu statistik dalam pengolahan data serta menarasikan hasil penelitian sebagaimana kutipan wawancara dengan mahasiswa berikut ini:

P : Teknik pengumpulan data dan teknik analisis data yang anda gunakan di bab 3 tidak sesuai dengan rumusan masalah penelitian anda. Mengapa demikian?

M-12 : Saya kurang paham dengan statistika penelitian makanya hanya mengutip dari punya teman.

$P \quad: \quad$ Iya, tapi kan rumusan masalah kalian berbeda dan anda juga sudah belajar statistika penelitian.

M-12 : Iya, hanya saja saja saya masih kurang paham dengan metode statistika makanya menuliskannya seperti itu.

Kesulitan membagi waktu kuliah dengan penyusunan proposal penelitian 
Mahasiswa yang mengambil mata kuliah seminar proposal berada pada semester VI dengan beban sks yang cukup tinggi berkisar antara 18-24 sks. Tuntutan tugas dari mata kuliah yang lain juga membuat mahasiswa kewalahan dalam penyusunan proposal. Kesulitan ini terjadi karena mahasiswa kurang mampu mengatur waktu dengan baik sehingga beberapa tugas mata kuliah dikerjakan tanpa skala prioritas dan kemampuan yang maksimal.

Berdasarkan observasi dan wawancara juga diperoleh faktor-faktor penyebab kesulitan mahasiswa dalam menyusun proposal penelitian berupa faktor internal dan eksternal. Faktor internal meliputi masih rendahnya kemampuan mahasiswa dalam memahami dan menyusun setiap konten dalam proposal penelitian, masih terdapat beberapa mahasiswa yang belum memiliki komputer atau laptop sendiri sehingga beralasan kesulitan dalam menyusun ide mereka dalam proposal secara lebih efisien menggunakan komputer atau laptop yang mereka sewa atau pinjam serta kurangnya motivasi mahasiswa untuk menyelesaikan proposal. Beberapa mahasiswa menyatakan bahwa akan segera berhenti mengerjakan proposal ketika menemui berbagai kesulitan. Faktor eksternal yaitu waktu mahasiswa yang tersita untuk kegiatan sosial maupun kerohanian di lingkungan rumahnya, beberapa mahasiswa yang sudah berkeluarga juga menyatakan kurang berkonsentrasi menyusun proposal ketika berada di rumah karena mengalami gangguan dari keluarganya serta kesibukan beberapa mahasiswa dalam mengerjakan tugas di rumah karena tinggal bersama pengampuh/orang tua wali. Hasil wawancara dengan mahasiswa disajikan pada kutipan berikut:

\begin{tabular}{|c|c|c|}
\hline$P$ & : & $\begin{array}{l}\text { Mengapa anda tidak melakukan perbaikan } \\
\text { pada proposal anda sesuai dengan yang sudah } \\
\text { saya sampaikan? }\end{array}$ \\
\hline$M-8$ & : & $\begin{array}{l}\text { Saya kesulitan membagi waktu untuk } \\
\text { mengerjakan tugas kuliah yang lain sehingga } \\
\text { tidak sempat memperbaiki proposal saya. }\end{array}$ \\
\hline$P$ & : & Iya, tapi kan perbaikannya tidak banyak \\
\hline$M-8$ & : & $\begin{array}{l}\text { Iya, hanya saya belum sempat mencari } \\
\text { referensi untuk perbaikan tersebut. }\end{array}$ \\
\hline
\end{tabular}

\section{KESIMPULAN DAN SARAN}

Berdasarkan analisis hasil penelitian maka dapat disimpulkan bahwa jenis-jenis kesulitan mahasiswa dalam menyusun proposal peneltian pendidikan matematika adalah kesulitan dalam menuangkan ide ke dalam bentuk tulisan ilmiah, membuat latar belakang masalah, mencari literatur/bahan pustaka, mengkaji keterkaitan teori yang digunakan menentukan metodologi penelitian serta membagi waktu kuliah dengan penyusunan proposal penelitian. Faktorfaktor penyebab kesulitan mahasiswa dalam menyusun proposal penelitian pendidikan matematika berupa faktor internal dan eksternal. Faktor internal meliputi masih rendahnya kemampuan mahasiswa dalam memahami setiap konten dalam proposal penelitian, masih terdapat mahasiswa yang belum memiliki komputer atau laptop sendiri serta beberapa mahasiswa kurang termotivasi dalam menyelesaikan proposal penelitiannya. Faktor eksternal meliputi terdapat mahasiswa yang terlibat dalam kegiatan sosial maupun kerohanian di lingkungan rumahnya, mahasiswa yang sudah berkeluarga sulit berkonsentrasi karena gangguan dari keluarganya serta kesibukan mahasiswa dalam menyelesaikan berbagai tugas di rumah karena tinggal bersama pengampuh/orang tua wali.

Berdasarkan simpulan maka dapat disarankan beberapa hal berikut: (1) dosen perlu menerapkan model pembelajaran yang lebih menarik dalam perkuliahan bidang kajian penelitian agar mahasiswa termotivasi dan semangat dalam belajar. (2) Perlu diadakan workshop penulisan proposal penelitian bagi mahasiswa selain kegiatan perkuliahan. (3) Mahasiswa harus lebih termotivasi dan tekun dalam menyusun proposal penelitian sehingga dapat menyelesaikan tugas akhir tepat waktu.

\section{DAFTAR PUSTAKA}

Asmawan, M. C. (2016). Analisis Kesulitan Mahasiswa Menyelesaikan Skripsi. Jurnal Pendidikan Ilmu Sosial, 26(2), 51-57.

Ayudia, dkk. (2017). Kesalahan Penggunaan Bahasa Indonesia dalam Laporan Hasil Observasi Siswa Sekolah Menengah Pertama. BASASTRA, Jurnal Penelitian Bahasa, Sastra Indonesia dan Pengajarannya, 5(2), 1-16.

Rismen, S. (2015). Analisis Kesulitan Mahasiswa dalam Penyelesaian Skripsi di Prodi Pendidikan Matematika STKIP PGRI. LEMMA, 1(2), 57-62.

Siregar, S. (2014). Statistik Parametrik untuk Penelitian Kuantitatif. Jakarta: Bumi Aksara.

Sugiyono. (2013). Metode Penelitian Pendidikan Pendekatan Kuantitatif, Kualitatif dan $R$ \& D. Bandung : Alfabeta.

Suryabrata, S. (2014). Psikologi Pendidikan. Jakarta: PT. Raja Grafindo Persada.

Syah, M. (2011). Psikologi Belajar. Jakarta: PT Raja Grafindo Persada.

Xia, W., dan Luxin, Y. (2012). Problems and Strategies in Learning to Write a Thesis Proposal: a Study of Six M. A. Students in a TEFL Program. Chinese Journal of Applied Linguistics (Quarterly), 35(3), 324-341. 